\title{
An Austrian Auden: A Media Construction Story
}

\section{Timo Frühwirth}

To cite this article: Timo Frühwirth (2019) An Austrian Auden: A Media Construction Story, Life Writing, 16:2, 159-175, DOI: 10.1080/14484528.2019.1540247

To link to this article: https://doi.org/10.1080/14484528.2019.1540247

\section{(2) 2018 The Author(s). Published by Informa UK Limited, trading as Taylor \& Francis Group \\ 曲 Published online: 07 Mar 2019.

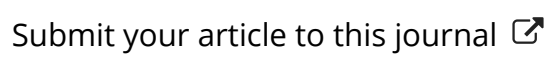

Џ Article views: 75

View Crossmark data $₫$ 


\title{
An Austrian Auden: A Media Construction Story
}

\author{
Timo Frühwirth \\ Department of English and American Studies, University of Vienna, Vienna, Austria
}

\begin{abstract}
W. H. Auden (1907-1973) was one of the most acclaimed writers in the English language in the twentieth century. When he divided his final fifteen years between the United States and Austria, in between foreign fame and local unknownness the poet materialised as a celebrity in Austrian television: it is a peripheral, small-nation media audience which the September-1967 episode of the documentary feature series Das österreichische Porträt [The Austrian Portrait] addresses and projects.

This paper investigates that televised biographical representation in terms of Stuart Hall's conceptualisation of the narrative construction of identity, with the help of tools from British Cultural Studies and film studies. The case study especially considers how - through audio-visual strategies that add up to a metaphorical manoeuvre - the Anglo-American poet's life and work in Austria are storied along those of Austrian poet Josef Weinheber, whose entanglement with National Socialism gets blanked out in the film.

It is in the specific context of a peripheral celebrity culture, and peripheral celebrity life writing, that the foreign identity is thus metaphorically translated into local frames of reference. The case study also has implications for TV documentary as a life-writing (or life-depiction) genre as regards its audio-visual rhetoric in the context of a discursive truth effect and the naturalised codes of televisual representation.
\end{abstract}

\section{KEYWORDS}

Celebrity; life writing; television documentary; W. H. Auden

\section{Auden in Austria}

In her review of studies of the Anglo-American writer W. H. Auden (1907-1973), Nadia Herman Colburn (2004) outlines the biographical logic that structures most Auden criticism along the distinction between Auden's American and English periods (242). Studies of the 'English Auden' (which is the title of Edward Mendelson's anthology of W. H. Auden's [1977] literary texts from 1927 to 1939) tend to examine the political dimension of his work, which builds upon the politically-oriented interwar reception of Auden's work. Two anthologies from the thirties - New Signatures from 1932 and New Country from 1933 - are the first to place Auden at the centre of a new group of politically engaged writers (Colburn 2004, 241). Christopher Isherwood and Stephen Spender, Louis 
MacNeice and Cecil Day-Lewis salute W. H. Auden in a special issue of New Verse in 1937; in 1938, New Verse proclaims the thirties and the thirties poets 'the Auden Age and the Auden Circle' (Carpenter 1981, 230; Firchow 2002, 74).

Auden's move to the United States in 1939 constitutes a biographical caesura. Auden received the Pulitzer Prize for his book-length poem The Age of Anxiety in 1948; in 1956, The Shield of Achilles won the National Book Award (Carpenter 1981, 347; Levy $1983,146)$. It is especially the moral aspects of his work in this period that studies of the 'American Auden' address (Colburn 2004, 242). In fact, however, Auden's American period is largely an American-European period: Auden summered on Ischia from 1948, and from 1958 in the Austrian village of Kirchstetten (Carpenter 1981, 360-361, 387-388).

Colburn's review concludes The Cambridge Companion to W. H. Auden, edited by Stan Smith, whose introduction challenges the England-America binary: 'Auden in later life deconstructed such binaries by adopting a third provisional location, reinventing himself as a European' (Smith 2004, 10). 'The European Auden' - the title of Edward Mendelson's contribution - implies a notion of continental Europe that excludes the British Isles but includes the Italian island of Ischia, highlighting Auden's poetic activity in Italy and Austria: the second half of the study indicates the specific relevance of Auden's Austrian period (Mendelson 2004, 66-67). A similar spatial logic structures the 2013 collection of essays W. H. Auden in Context, edited by Tony Sharpe. Justin Quinn, in his chapter 'At Home in Italy and Austria, 1948-1973' - as well as in his essay 'Auden's Cold War Fame' in the 2015 collection Auden at Work, edited by Bonnie Costello and Rachel Galvin - highlights how, in that period, Auden's summer homes afforded him greater opportunities to write poetry than his life in the United States (Quinn 2013, 56; 2015, 243). Indeed, in the mid-1960s, it was during the Austrian summers that Auden did most of his writing (Burstall 1965b, 24).

The 1960s also mark a new turn in Auden criticism with a marked focus on the private and psychological; John Updike's (1966) review of Auden's (1966) collection of poems About the House is emblematic of this reception (Seidl 2014, 406): 'As a young man, his concern was more with "public space," and he remains the poet of the foreboding that preceded World War II, the lucid exhausted voice of "September 1, 1939." ... As an aging post-war man, he has turned more toward the "inner space," the landscape of his will and need' (Updike 1966, 235-236).

In her 2014 study of the sequence of poems Thanksgiving for a Habitat, which is included in Auden's About the House, Monika Seidl reviews the press, radio, and television coverage of Auden during his Austrian period, and highlights how contemporary media images of the author, such as TV producer Christopher Burstall's leading article in The Sunday Times (1965b), incline toward the anecdotal (Seidl 2014, 394-395). In 1965, Burstall visited Auden in Kirchstetten to prepare a documentary for BBC One. Before the film was aired, he wrote in The Sunday Times,

We whizzed on in the Volkswagen through the heavy, rich, unspectacular countryside, for Auden likes to drive hard and fast.... Auden bounded from the car and impetuously shuffled, in his broken-down woolly carpet slippers, up the long narrow track. (Burstall 1965b, 24)

While that may be how Kirchstetteners first encountered the foreign poet, unlike Burstall they had not 'been reading his poems for as long as I can remember' (Burstall 1965b, 
24); nor, for that matter, were they the readers implied by Burstall's report, which presupposed cultural knowledge of Auden as 'the enfant terrible of the thirties' (21). Yet in between foreign fame and local unknownness, Auden materialises as a celebrity in the Austrian media. An Austrian TV documentary on Auden from 1967 features interviews with the Kirchstetten mayor, the schoolmaster, and the priest:

One Sunday morning, he stood in front of the church door and introduced himself as Winston [sic] Auden.... Afterwards, I looked him up in the encyclopaedia and learned some facts about him: that he is an English poet, who moved to America in 1939; notably, I also encountered his important work, The Age of Anxiety. ${ }^{1}$ (Holzinger 1967, 00:09:2500:10:03)

It is the cultural authority of the encyclopaedia that endows the foreigner with significance. However, it is a specifically local significance which the schoolmaster highlights: 'In Professor Auden we again have a poet and professor in Kirchstetten, as Josef Weinheber was until 1945' (00:16:59-00:17:07). ${ }^{2}$ After quickly enumerating Auden's international awards, the voice-over commentary concludes, 'It is understandable, therefore, that the Kirchstetteners have been proud of their poet since they learned of his fame' (00:18:48-00:18:53). ${ }^{3}$ The Mayor of Kirchstetten expands:

When he first came to Kirchstetten in 1958, one would not think much about him dangling through the village. And it was said that he was an American poet, and not much attention was paid to him.... Now word has spread in the press, on the radio and television that we have a very famous poet in our village, and now he is revered and esteemed.... We are very proud that yet again we have such a famous poet in Kirchstetten. ${ }^{4}$ (00:19:00-00:19:37)

In the Kirchstetten of the 1960s, Auden was famous for being famous elsewhere. The meanings that make the unknown foreigner famous are made in the press, on the radio and television': it is the media phenomenon of celebrity that bridges the gap between unknownness and fame. Relevant here is Daniel J. Boorstin's definition of the celebrity as a person made meaningful through media representation:

The celebrity is a person who is known for his well-knownness.

His qualities-or rather his lack of qualities-illustrate our peculiar problems. He is neither good nor bad, great nor petty. He is the human pseudo-event.... The product of no conspiracy, of no group promoting vice or emptiness, he is made by honest, industrious men of high professional ethics doing their job, 'informing' and educating us. He is made by all of us who willingly read about him, who like to see him on television. (1962, 57-58)

Boorstin concludes, 'the celebrity is created by the media' (61). Inasmuch as Boorstin conceives of celebrity in terms of media circulation, and explicitly not of 'achievement' (61), his concept precludes the accomplishments of 'literary art' (153). In relation to W. H. Auden's entry into the 'peripheral' small-nation celebrity culture of Austria, the Boorstinian concept of 'celebrity' can help shed light on the disconnection between the poet's foreign (from the point of view of 1960s Austria) 'qualities' and his local significance. $^{5}$

While Boorstin's study of celebrity explicitly engages with American media systems in the early 1960s, celebrity studies has more recently turned its attention to peripheral celebrity culture in small nations (Williams 2016, 154-155). The dynamics of small-nation celebrity touch on themes at the interface between the foreign and the local: conditions 
of in-between-ness and liminality; negotiations of celebrity identity in the context of nationhood; small-nation politics of celebrity; and the representational regimes in small-nation media cultures. ${ }^{6}$ This is the context in which this case study sets out to examine the 1967 Austrian TV documentary on W. H. Auden as a particular case of audio-visual celebrity life writing. The broad notion of 'life writing' employed here is close to Nigel Hamilton's concept of 'life depiction,' which explicitly addresses biographical representations across media (2007, 2-3), the term 'depiction' seeming particularly suitable to address (audio-)visual biographical representations. Exploring television as a life-writing medium will involve analysing the articulation of identity on the level of the complex televisual sign. In order to critically assess this specific form of mass-media representation, the following section will turn to the conceptual and methodological inventory of British Cultural Studies and film studies.

\section{An 'Austrian Auden'}

What the Austrian television film on W. H. Auden, as a specific instance of mass-media representation, involves is a moment of selection which for Raymond Williams is constitutive of all culture to the extent that it is not 'the lived culture of a particular time and place, only fully accessible to those living in that time and place': 'There is the recorded culture, of every kind, from art to the most everyday facts: the culture of a period. There is also, as the factor connecting lived culture and period cultures, the culture of the selective tradition' $(1961,66)$. All documentary record is subject to the interplay of selection and rejection, Williams notes: 'The selective tradition thus creates ... the historical record of a particular society... [and], most difficult to accept and assess, a rejection of considerable areas of what was once a living culture' (68). Consequently, Williams insists on the need to uncover the dominant system of societal interests which informs such selectivity (68).

Cultural Studies theorist Stuart Hall identifies the construction of national identity as a 'classic example' of Williams's 'selective tradition' $(1999,5)$. For Hall, it is through processes of selection that identity is constructed 'by "storying" various random incidents and contingent turning points ... into a single, coherent, narrative':

Like personal memory, social memory is highly selective. It highlights and foregrounds, imposes beginnings, middles and ends on the random and contingent. But equally, it foreshortens, silences, disavows, forgets and elides many episodes which - from another perspective - could be the start of a different narrative. (5)

For Hall, the articulation of identity, therefore, is achieved by means of literary strategies also in non-literary discourse. Questions of text and textual analysis are relevant here: while British Cultural Studies owes expanded notions of 'text' and 'textuality' to its encounters with semiotics, structuralism, and poststructuralism (Hall 1996, 270), it is through the encounter with literary criticism that a 'close reading' of texts in this expanded sense, which includes the analysis of popular media such as television, has been one of the key methods in the Cultural Studies toolkit (Ang 2008, 245).

In the following I will undertake such a close reading of a filmic text: the 28-minute episode 'W. H. Auden' of the documentary feature Das österreichische Porträt [The Austrian Portrait], directed by Dieter O. Holzinger, and broadcast by national public-service broadcaster Österreichischer Rundfunk [Austrian Broadcasting Corporation] on 3 
September 1967. Between 27 December 1965 and 21 June 1970, twenty episodes were aired to portray famous Austrians. Episode twelve differs from the others, as the narrator notes: 'This time, calling it "An Austrian-American Portrait" would actually be more accurate' (Holzinger 1967, 00:00:34-00:00:39). ${ }^{7}$

But difference in this instance is smoothed out by similarity. Notably, the central sequence of the film - 00:10:48 to 00:16:36 - draws a close analogy between the AngloAmerican poet W. H. Auden and the Austrian writer Josef Weinheber (1892-1945). Weinheber was a renowned poet when he moved to Kirchstetten in 1936 (Berger 1999, 164). After 1938, he became deeply involved in the politicised cultural scene of Nazi Germany - Weinheber's biographer Albert Berger (2003) contrasts the poet's 'self-critical as well as self-confident position of retreat' especially in his late work with his 'public appearance as a cultural representative of the Third Reich' (151). 'Hymnus auf die Heimkehr' ['Hymn to the Home-Coming'] is the title of Josef Weinheber's contribution to the 1938 Bekenntnisbuch österreichischer Dichter [Austrian Writers' Book of Allegiance], which hails the Austrian Anschluss (the annexation of Austria into Nazi Germany in 1938) (Berger 1999, 168); Weinheber's three odes 'Blut und Stahl' ['Blood and Steel'] from 19401941 include 'Hymnus auf den Frontarbeiter' ['Hymn to the Front Worker'], 'Hochgesang auf den deutschen Rüstungsarbeiter' ['Anthem to the German Arms Worker'] and 'Ode an die Straßen Adolf Hitlers' ['Ode to the Streets of Adolf Hitler'] (Berger 1999, 303). In 1944, the poet's name was included in Adolf Hitler and Joseph Goebbels's Gottbegnadeten-Liste [List of the Divinely Gifted] as a strategically important writer of the home-front 'Künstlerkriegseinsatz' ['artistic war effort'], which exempted Weinheber from military service (Berger 1999, 277; Rathkolb 1991, 173, 176). Weinheber eventually committed suicide in Kirchstetten on 8 April 1945 (Berger 1999, 11).

The film sequence in the 1967 TV documentary is symmetrically structured. The voiceover narration, spoken by Austrian actor Alexander Trojan, introduces a chiastically arranged (Auden/Weinheber and Weinheber/Auden) extended simile:

Just like Wystan Auden now, more than twenty years ago Josef Weinheber sat in this church. Weinheber dedicated countless poems to his adopted home Kirchstetten. ${ }^{9}$ (00:10:5100:11:02)

And:

In the tavern next to the church, Josef Weinheber had his regular table, just like Wystan Auden today. And he too has dedicated poems to Kirchstetten. ${ }^{10}$ (00:12:10-00:12:21)

Both passages are followed by recitations of poetry: the sixth stanza of Josef Weinheber's (1996) poem 'Kirchstetten' from 1940 (00:11:06 to 00:11:52); and an abridged version of W. H. Auden's 1965 poem 'Joseph [sic] Weinheber (1892-1945)' (00:13:09 to 00:16:21). Both poems include appreciations of the Kirchstetten panorama; in Weinheber's poem, this reads as follows (in Peter Edgerly Firchow's [2008] English translation):

There's the church, the graveyard, the tavern,

The basic necessities of life and death-

Everything's handy, right here in the village.

First a few little streets, gables, a house,

Then off you go into the wide-open meadows,

Where the woods creep upward along the edge. ${ }^{11}$ (Firchow 2008, 229) 
In Auden's poem, the landscape is described thus:

Looking across our valley

Where, hidden from view,

Sichelbach tottles westward

To join the Perschling,

Humanely modest in scale

And mild in contour,

Conscious of grander neighbours

To bow to, mountains

Soaring behind me, ahead

A noble river. ${ }^{12}$ (00:15:45-00:16:03; Auden 1965, 24)

The audio track of W. H. Auden's reading of his English-language poem is overlaid with the audio track of Alexander Trojan's voice-over recitation of the German translation of the poem (see footnote 12). It thereby acoustically approximates Trojan's earlier recitation of Weinheber's German-language poem (footnote 11), which is superimposed over an audio track of scored music. Both times the camera moves horizontally along fields and meadows and uphill along a shelterbelt band of trees, following the route described in Weinheber's poem 'Kirchstetten': Figure 1.

There is a close visual correspondence, which unfolds in the twin syntax of the filmic language: in the linear sequence of framed images in time, and the composition of lexical units - their mise-en-scène - within the space of the individual image frame. ${ }^{13}$ In the black-and-white pictures, the two-dimensional geometry of the frame is organised in terms of the shape and relative disposition of areas of different lightness: corresponding relations between areas of high-value and mid-value intensity, on the one hand, and areas of low-value intensity, on the other, as well as corresponding angles of diagonals add up to an equivalence between the images compared in Figure 1 with regard to the spatial syntagm. There is equivalence, too, regarding the temporal syntagm of the continuous shots in terms of camera movement when, both times, the camera pans from left to right and tilts slightly upwards. Equivalent dynamic shots thus combine equivalent static images to establish a close visual correspondence between the two scenes within the double syntaxspatial and temporal - of the film. It is the correspondence between syntactic constructions that defines parallelism as a figure of style (Baldick 2015, 266), which involves a semantic of corresponding meanings of distinct elements (Mayoral 2001, 553; Nadin 1998, 465): the parallelism that shapes the successive presentations of Weinheber's and Auden's poems thus implies an affinity between the two poems and (by means of a voice-over framing that suggests an autobiographical reading) the two poets.

A related semantic of linking distinct elements, but also of imposing one element on another, is involved in the editing technique of the dissolve (also called mix in television), which superimposes a fade-in over a fade-out (Monaco 2009, 248-249): towards the end of the central sequence in the film, a dissolve transition superimposes the fading-in photograph of Josef Weinheber over the fading-out footage of W. H. Auden. That transition, moreover, follows the rules of a match dissolve, in which the dissolve bridges a match cut between two similarly composed image frames (Kroon 2010, 408): within the geometry of the frame plane, the representations of Auden's and Weinheber's left eye coincide when one head-and-shoulder shot transforms into the other. The semantic of matching misesen-scène, from a structuralist perspective, adds up to a 'metaphorical parallelism' (Galan 

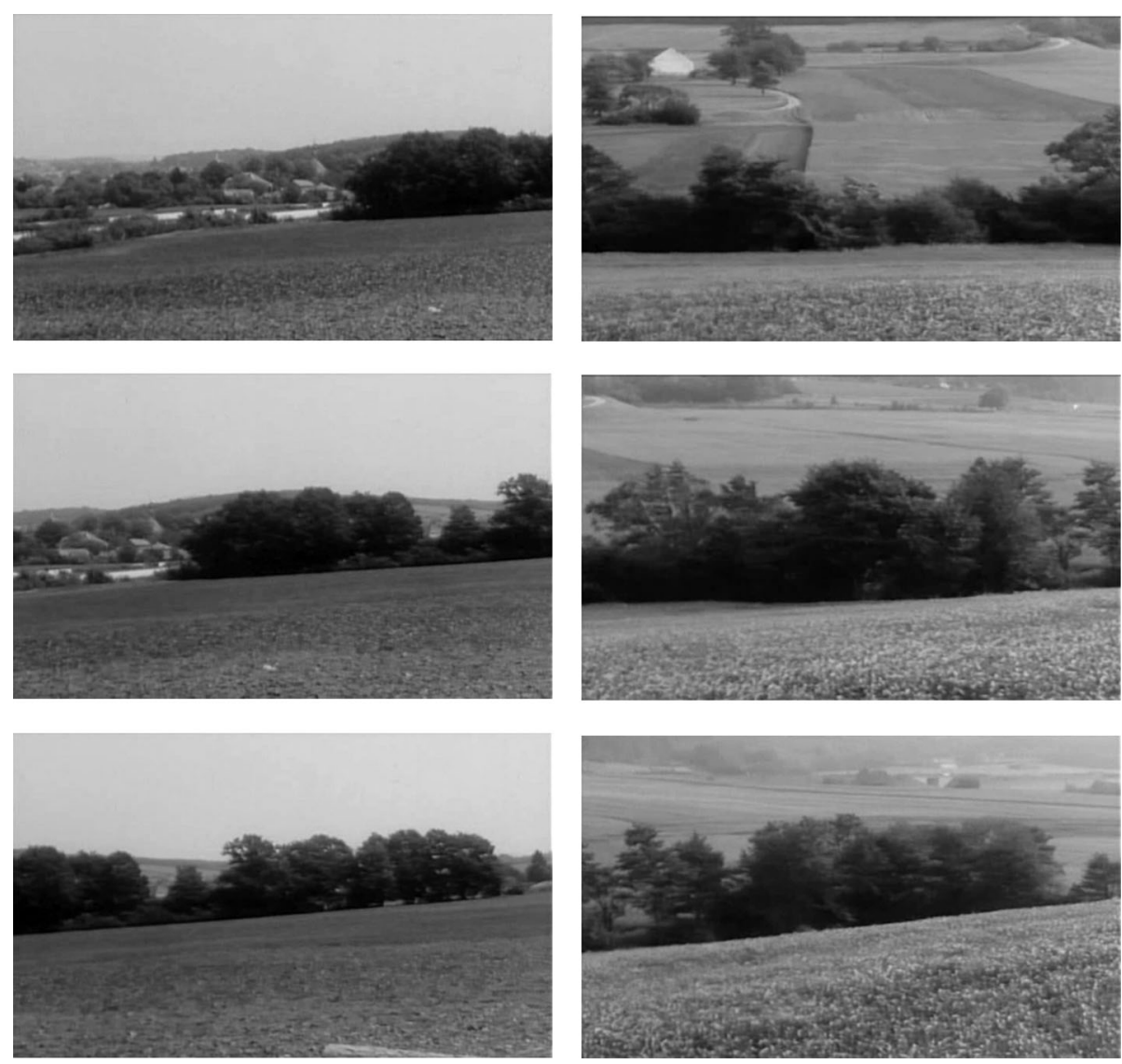

Figure 1. "W. H. Auden," Das Österreichische Porträt: screenshots at three-second intervals from 00:11:42 to 00:11:48 (left) and from 00:15:53 to 00:15:59 (right).

$1985,100)$, which the match dissolve establishes while at the same time it blurs changes in location and time (Kroon 2010, 408). When they overlap, momentarily, the two images fuse: Figure 2.

The fusion of images in the match dissolve exactly coincides with the fusion of poetic voices in Auden's poem 'Joseph Weinheber,' which integrates a quotation from Josef Weinheber's (1972b) poem 'Kammermusik (Eine Variation)' ['Chamber Music (A Variation)'] from 1939: 'Bratsche: / Mein grauer Scheitel macht es mir zur Pflicht, / den Abgrund euch zu nennen' ['Viola: / My grey hair obliges me / to name you the abyss'] (442). When, in Auden's poem, the lyrical speaker adapts the words from Weinheber's poem to the speaker's own syntax - 'den / Abgrund zu nennen' - momentarily, the two poetic voices blend into one another. Both poetic voices materialise in the TV film through the same (physical) voice of the Austrian actor's German-language voice-over, which ends the sequence with another Weinheber/ Auden simile:

As proud as the Kirchstetteners are of Josef Weinheber - they have named a square and even the elementary school after him - they are as proud of Wystan Auden. ${ }^{15}$ (00:16:26-00:16:35) 
A2: Spiel der Bratschen / Auf ungezäunten Rasen A1: On the impaled green, / Committed thereafter

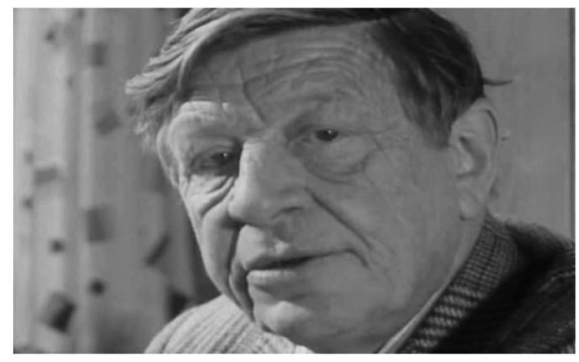

A2: zu hören, / Und dem es später oblag, den / A1: den / Abgrund zu nennen.

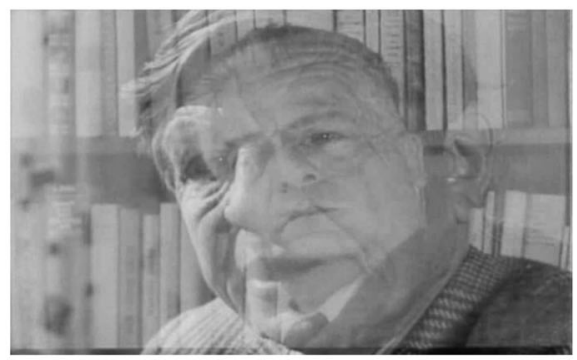

A2: Abgrund zu nennen.

A1: [music]

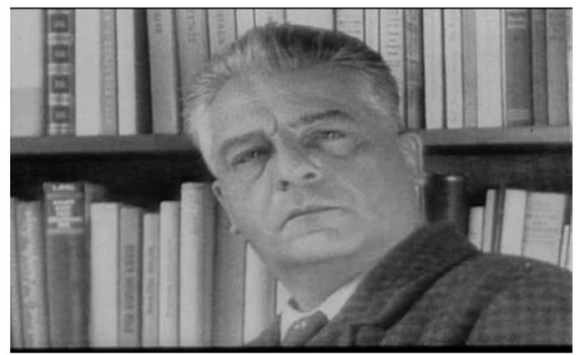

Figure 2. "W. H. Auden," Das Österreichische Porträt: screenshots at a three-second interval from 00:16:15 to 00:16:21 together with synchronised transcriptions of audio tracks. ${ }^{14}$

Beyond the linguistic construction of similitude, the film acoustically and visually constructs sameness: the visual language and soundtrack of the filmic text intensify the linguistic simile into a metaphor, in that parallelism (of static images and dynamic shots) and superimposition (of image and sound) bypass an explicit comparison. While metaphor is, syntactically, an elliptic form of simile, omitting explicit markers such as 'as' and 'like,' in semantic terms this means a qualitative change in meaning from likeness to identity (Lanham 1991a, 100; 1991b, 140).

It is thus that the filmic language of the televisual text constructs a specific viewing position. More than a figure of speech, metaphor defines a mode of thought for literary theorist Kenneth Burke: in his discussion of tropes, Burke is primarily concerned 'not with their purely figurative usage, but with their rôle in the discovery and description of "the truth" $(1969,503)$. For Burke, '[m]etaphor is a device for seeing something in terms of something else. It brings out the thisness of a that, or the thatness of a this' (503). Such metaphorical displacement of meaning (Greek $\mu \varepsilon \tau \alpha \varphi \varepsilon$ é 'Weinheber-ness' of Auden, and an 'Auden-ness' of Weinheber, is not innocent of politics: when the life and work of W. H. Auden are metaphorically re-written along the lines of the (itself highly selective) story of the Kirchstetten poet Josef Weinheber, in a double 
movement, the life and work of the Austrian poet are re-written, and re-deemed, by metaphorical analogy to the Anglo-American writer. What that metaphorical manoeuvre, which involves seeing one in terms of the other (rather than seeing each on their own terms), critically relies on are selective strategies that overemphasise the similarities, and override the differences, between the Anglo-American Pulitzer-Prize winner and the Nazi-Germany poet laureate.

In his 'Notes on W. H. Auden's Poem “Joseph Weinheber," Hermann Schlösser (2014, 381-382) discusses the integration of Weinheber's poetry into Auden's Weinheber poem in relation to another passage:

What, had you ever heard of

Franz Jägerstätter,

The St Radegund peasant

Who said his lonely

Nein to the Aryan State

And was beheaded,

Would your heart, as Austrian,

Poet, have told you?

Good care, of course, was taken

You should hear nothing,

Be unprepared for a day

That was bound to come,

A season of dread and tears

And dishevelment

When, transfixed by a nightmare,

You destroyed yourself.

Retribution was ever

A bungler at it:

Dies alles ist furchtbar, hier

Nur Schweigen gemäss. (Auden 1965, 22)

In the fifth stanza of his poem from 1965, Auden has reworked an elegiac couplet from Weinheber's (1972a, 290) pessimistic-existentialist (Berger 1999, 200) 1936 poem 'Auf das Unabwendbare' ['On the Inevitable']: 'Nein, es wäre zuviel. Und langt nicht. Dies alles ist furchtbar. / Schau nicht! Wende dich! Schweig! Hier ist nur Schweigen gemäß' ['No, it would be too much. And is not enough. This all is dreadful. / Don't look! Turn around! Silence! Here, only silence is appropriate' (second line Schlösser's translation in Schlösser 2014, 382)]. But the fourth and fifth stanzas of Auden's poem are omitted in the film. What is therefore excluded from the Austrian television profile is not only the conscientious objector Franz Jägerstätter's 'lonely / Nein to the Aryan State,' but also the reference to Josef Weinheber's suicide in the final days of the Nazi regime.

Likewise, the film includes the unproblematic sixth stanza of Weinheber's poem 'Kirchstetten' from 1940 quoted further above, but excludes the fourth and ninth stanzas, which contain the ideologically fraught terms 'heimisch' ['native'] $(1996,479)$ and 'Heimaterde' ['native soil'] (1996, 480), connoting the National Socialist politics of 'Blood and Soil.' Such selectivity partakes in constructing an image of the Austrian poet that is not easily compatible with Weinheber's politically charged poetry, such as his 1939 acrostic 'Dem Führer' ['To the Führer']: 
Germany's genius, Germany's heart and head,

Germany's honor, despoiled so long.

Might of the sword, wherein the world believes.

Fifty years, and a work of bronze,

Larger than life, built of pain,

Light and holy, storming heavenward.

Saviour, redeemer, conqueror of night,

Reap, endure-you too-bay leaves and song:

Find rest in our love, live long. ${ }^{16}$ (Firchow's translation in Firchow 2008, 225)

In the same way, the Austrian Portrait features lines from W. H. Auden's poem 'Joseph Weinheber,' but not the uneasy, unapologetic poetry for which he had become famous elsewhere; nor, for that matter, any of his poetry written between 1927 and $1965 .{ }^{17}$ Like Weinheber's acrostic, the following lines by Auden (1940) are from 1939-three stanzas from 'Refugee Blues,' whose poetic figuration of the hardship of those who flee National Socialist persecution is difficult to reconcile with the politics of Weinheber's poetic praise of Hitler: ${ }^{18}$

Say this city has ten million souls,

Some are living in mansions, some are living in holes:

Yet there's no place for us, my dear, yet there's no place for us.

Thought I heard the thunder rumbling in the sky;

It was Hitler over Europe, saying; "They must die":

$\mathrm{O}$ we were in his mind, my dear, $\mathrm{O}$ we were in his mind.

Saw a poodle in a jacket fastened with a pin,

Saw a door opened and a cat let in:

But they weren't German Jews, my dear, but they weren't German Jews. (85-86)

Such selectivity, which amounts to a 'rejection of considerable areas' (Williams 1961, 68) of the poet's 'qualities' (Boorstin 1962, 57), is effective in the context of a celebrity life writing that addresses - and projects (as a function of the audio-visual text) - a media audience on the periphery: in the context of a small-nation, peripheral celebrity culture, and the media construction of an 'Austrian Auden,' W. H. Auden's achievements are beside the point inasmuch as the 'lack of qualities' (created through selection) coincides with the metaphorical transfer of a localised significance from (a selective, denazified version of) Josef Weinheber. Conversely, these 'qualities,' omitted in the Austrian Portrait, are very much to the point in the context of the Anglophone, large-nation celebrity culture in which British television partakes. In this context, Auden's literary reputation is incompatible with a Boorstinian concept of celebrity that excludes the notion of 'achievement.' Yet, in the contemporaneous media construction of an 'English Auden,' which addresses, and projects, a different media audience, selectivity is at work no less, as the poet's present life and work is bracketed in favour of a spatially defined section of past achievements. 


\section{An 'English Auden' in Austria}

It is in another TV profile from the mid-1960s that the above-quoted stanzas from Auden's 1939 'Refugee Blues' feature: the 35-minute television film 'Poet of Disenchantment: W. H. Auden,' written and produced by Christopher Burstall (1965a), and broadcast in the weekly feature series Sunday Night on BBC One on 28 November 1965. This 1965 $\mathrm{BBC}$ profile will be discussed in this section as another example of celebrity life writing through the medium of TV documentary.

The BBC interview with interlocutor Peter Duval Smith was pre-recorded on 19 September in the poet's Kirchstetten home, from which occasion dates the now-famous Auden quote, 'Your cameraman might enjoy himself because my face looks like a wedding-cake left out in the rain' (Burstall 1965b, 24). Christopher Burstall reads the voice-over commentary, which situates the interview in an underwhelming Austrian countryside:

The autobahn from Vienna to Salzburg runs along the edge of a field a quarter of a mile away, and across this unsurprising landscape the noise of the traffic carries faintly through the night and day to Auden's farmhouse, which leans against the wooded hillside. (Burstall 1965a, 2-3)

In another sequence, W. H. Auden's artistic collaborator Igor Stravinsky requests, 'Wystan has been in Austria too long now and I wish you could convince him to come back. After all, we can't afford to give our best poet to the Germans' (1965a, 18). ${ }^{19}$

The study of Auden's Austrian summer home, Burstall notes, is 'cluttered with books, paper, work in progress' (5). When he concludes, 'W.H. Auden, a greatly gifted poet, alert to the past, actively writing and living in the present' (23), however, what follows is poetry from Auden's past: the film ends with Auden's 'As I Walked Out One Evening' from 1937, just as it starts with a reference to the 1937 edition of New Verse, and to Isherwood, Spender, MacNeice, and Day-Lewis (24). Except for a single five-word quotation, in the voice-over commentary, from the 1965 sequence Thanksgiving for a Habitat - 'silence is turned into objects' (5) - the BBC profile includes no poetry from Auden's Austrian period. Nor, for that matter, any of Auden's poetry from after 1948. The film features altogether fourteen poems, read by English actors Susannah York, Tony Church, and Ian Holm and by W. H. Auden himself. Besides Auden's 1948 'In Praise of Limestone,' as well as 'Eyes Look Into the Well' and 'New Year Letter' from 1940, all poetry recited is from the thirties: ten of the fourteen poems that feature in the 1965 BBC film form part of Edward Mendelson's anthology The English Auden.

Halfway through the film, the interview touches upon Auden's decision to leave England for America in 1939, and the disappointment, on the part of the political left, over his emigration:

DUVAL SMITH: There's been a tremendous amount of criticism, which continues to this day, of your decision: impertinent criticism, I would agree with you, but -

AUDEN: People have every right to make it -

DUVAL SMITH: - but in a way criticism that you might care to answer.

AUDEN:

No, I won't answer that kind of thing. I mean, I know that it was right for me to do, and in fact I only felt that I'd discovered who I was after I got to America. (Burstall 1965a, 12-13)

In The Spectator from 3 December 1965, broadcasting executive and media scholar Stuart Hood records his personal response to the programme: 'I wondered, watching 
him talk to Peter Duval Smith in this week's Sunday Night feature on BBC-1,... whether he would talk about the motives which led him to leave England in 1939 and become an expatriate poet ... ; but that he was unwilling or unable, at this distance in time, to discuss a decision which can still kindle the very strongest feelings was a grave disappointment' $(1965,17)$. Then again, the programme was generally well received by TV critics (Davenport-Hines 1995, 323), ${ }^{20}$ and what the interview does not accomplish, the programme design achieves by virtue of selection when presenting Auden's poetry: to create continuity where there is discontinuity both in time and space, and to perpetuate W. H. Auden's Englishness beyond the biographical caesura of his move to America, largely disregarding his life and work in the US, Italy, and Austria. It is by means of the interplay of selection and rejection that the BBC's 'Poet of Disenchantment' can tell the story of an 'English Auden' at a time when Auden had lived outside England for more than twenty-five years.

\section{Conclusion}

In between competing media stories, a distinctive poetics and politics of celebrity life writing begin to emerge. In both the 1965 BBC profile and the Österreichischer Rundfunk film portrait from 1967, television documentary articulates identity. In direct comparison to each other, the narrativity of both articulations becomes visible, that is, their respective strategies of 'storying' (Hall 1999, 5) celebrity identity, which in each case depend on processes of selection. In his reflections on the selectivity of historical records, Raymond Williams notes that selection, within any given society, 'will always tend to correspond to its contemporary system of interests and values' $(1961,68)$ : "Thus "documentary" analysis will lead out to "social" analysis, whether in a lived culture, a past period, or in the selective tradition which is itself a social organization' (70). That is the context in which this case study of celebrity mediatisation has been situated. If, as Graeme Turner suggests, celebrity can be approached 'as a media process that is coordinated by an industry, and as a commodity or text' $(2014,23)$, the comparison of the two documentary films demonstrates that in each of them such 'text' takes the shape of a narrative that is storied alongside society's 'contemporary system of interests and values.'

What emerges in between such nationalised celebrity mediatisations, too, are implications for the study of peripheral, small-nation celebrity culture: in the Austrian Portrait of W. H. Auden, as an instance of peripheral celebrity life writing, the narrative constructed has been shown to essentially involve a metaphorical transfer of meanings, on the level of the televisual sign, that renders the foreign identity readable 'in terms of (Burke 1969, 503) local frames of reference, in the course of which both the foreign identity and the local frames are modified. In that this semantic transfer displaces meanings of (literary) accomplishment, the 'Austrian Auden' figures as a Boorstinian celebrity - whose being 'known for his well-knownness' is exclusively a function of media circulation - in the context of the peripheral, small-nation celebrity culture of 1960s Austria.

The case study of the 1967 Austrian TV profile of W. H. Auden has, furthermore, implications also for life writing as a discipline and critical practice. Especially, television documentary as a life-writing genre would seem to involve a specific persuasive potential. For one, such potential can be related to the status of the documentary genre within what Foucault (1979) describes as a society's 
regime of truth, its 'general politics' of truth: that is the types of discourse it harbours and causes to function as true: the mechanisms and instances which enable one to distinguish true from false statements, the way in which each is sanctioned; the techniques and procedures which are valorised for obtaining truth: the status of those who are charged with saying what counts as true. $(1979,46)$

While this study has implied that literary strategies are at work in fiction and nonfiction alike, what distinguishes the nonfiction genre of TV documentary from the genres of fiction is a truth effect that aligns it with nonfiction genres across media. Moreover, this truth effect of the documentary genre is, from a Cultural Studies perspective, intensified by the 'naturalized codes' of the 'televisual image,' which for Stuart Hall are constitutive of dominant notions of the "transparent representation of the "real"' in the television discourse (1980, 121-122): the ideology of television as a transparent medium - simply showing us "what is happening," in Charlotte Brunsdon and David Morley's terms $(1978,9)$. As Hall critically remarks, this notion of 'transparency' coincides with television producers' emphasis on 'facilitating the "effectiveness" of their communication' (Hall $1980,124)$ - what Boorstin characterises ironically as the work of 'honest, industrious men of high professional ethics doing their job, "informing" and educating us' (1962, 58). For Hall, it is precisely because professional broadcasters will often not overtly bias their operations in a dominant direction that dominant meanings become encoded 'behind men's backs':

The professional code is 'relatively independent' of the dominant code, in that it applies criteria and transformational operations of its own, especially those of a technico-practical nature. The professional code, however, operates within the 'hegemony' of the dominant code. Indeed, it serves to reproduce the dominant definitions precisely by bracketing their hegemonic quality and operating instead with displaced professional codings which foreground such apparently neutral-technical questions as visual quality, news and presentational values, televisual quality, 'professionalism' and so on. $(1980,126)$

Such foregrounding of the technical realisation of an apparently 'transparent representation of the "real"' suspends the question to which extent the 'real,' in television, is in fact a function of representation, that is, of the complex audio-visual meaning-making of televisual film. It is in order to spotlight the often inconspicuous and (hence all the more) effective filmic rhetoric of sound and image - which escapes the analysis of text in the narrow sense of the word - that this study has employed an expanded notion of 'life writing.'

Quotations from W. H. Auden's poems 'Joseph Weinheber' and 'Refugee Blues' are reproduced with the permission of the Estate of W. H. Auden.

Screenshots from the episode 'W. H. Auden' of the documentary feature Das österreichische Porträt are reproduced with the permission of Österreichischer Rundfunk.

\section{Notes}

1. 'An einem Sonntagvormittag stand er vor dem Kirchenportal und stellte sich als Winston [sic] Auden vor. ... Nachher sah ich im Lexikon nach und erfuhr so einige Daten über ihn: dass er englischer Dichter sei, 1939 nach Amerika übersiedelte; besonders auch sein wichtiges Werk lernte ich kennen, Das Zeitalter der Angst' (Holzinger 1967, 00:09:2500:10:03). Unless otherwise indicated, all translations and audio transcriptions are by the author. 
2. 'Mit Professor Auden haben wir wiederum einen Dichter und Professor in Kirchstetten, wie es bis 1945 Josef Weinheber war' (00:16:59-00:17:07).

3. 'Verständlich also, dass die Kirchstettner stolz auf ihren Dichter sind, seit sie um seine Berühmtheit wissen' (00:18:48-00:18:53).

4. 'Wie er 1958 nach Kirchstetten kam, hat man sich eigentlich nicht viel vorgestellt, wie er durch den Ort schlenkert. Und man hat erfahren, dass er ein Dichter sei, ein amerikanischer. Und jetzt eigentlich hat man ihm nicht viel Beachtung geschenkt. ... Jetzt hat man erfahren, durch die Presse, Rundfunk und Fernsehen, dass wir einen sehr einen [sic] berühmten Dichter in unserem Ort haben. Und jetzt wird er verehrt und geschätzt. ... Wir sind stolz, dass wir wieder in Kirchstetten einen so einen berühmten Dichter haben' (00:19:0000:19:37).

5. Austria had a population of less than 7.5 million in 1967. Until 1989, the Central European country bordered on the 'Iron Curtain' and was therefore situated on the very periphery of the 'West' in Cold-War Europe.

6. These are themes addressed in the 2016 call for papers for Liminal Celebrity and Small Nations, a special issue of Celebrity Studies edited by Barry King and Damion Sturm.

7. 'Diesmal müsste es richtiger "Ein österreichisch-amerikanisches Porträt" heißen' (Holzinger 1967, 00:00:34-00:00:39).

8. Berger (2003): 'selbstkritischen wie selbstbewussten Rückzugshaltung'; 'öffentlichen Auftreten als kultureller Repräsentant des Dritten Reiches' (151).

9. 'So wie Wystan Auden jetzt, saß vor mehr als zwanzig Jahren Josef Weinheber in dieser Kirche. Weinheber hat seiner Wahlheimat Kirchstetten unzählige Gedichte gewidmet' (00:10:51-00:11:02).

10. 'Im Gasthaus neben der Kirche hatte Josef Weinheber seinen Stammtisch, so wie ihn heute auch Wystan Auden hat. Und auch er hat Gedichte über Kirchstetten geschrieben' (00:12:1000:12:21).

11. 'Da die Kirche, der Friedhof, der Wirt: / Wie's dem Leben und Sterben gebührt, / alles nah bei der Hand und im Orte; / die paar Dorfgassen, Giebel und Haus, / und schon läufts in die Flurbreiten aus, / hanghinauf zieht der Wald seine Borte' (00:11:06-00:11:52; Weinheber 1996, 480).

12. 'Schaue ich über unser Tal, / Wo, dem Blick entzogen, / Der Sichelbach westwärts eilt, / Um mit der Perschling sich zu vereinigen - / Ein menschlich bescheidenes Bild / Und sanft in den Konturen -, / Bin ich mir der bedeutenden Nachbarn bewußt, / Die ich verehre: der Berge, / Die hinter mir aufragen, vor mir / Des prächtigen Flusses' (00:15:45-00:16:03; Auden 1973, 139). The spelling and punctuation of this Germanlanguage audio transcript follow Herbert Heckmann's almost identical translation of the stanza: instead of 'der bedeutenden Nachbarn' ['of the grand neighbours'] in the film, however, Heckmann writes 'bedeutenderer Nachbarn,' which more closely corresponds to Auden's 'of grander neighbours.' Herbert Heckmann had worked on the translation in collaboration with W. H. Auden before it was first published in Frankfurter Allgemeine Zeitung in 1972.

13. The terminology deployed in the filmic analysis is based on the descriptive vocabularies proposed by Rick Altman (1999) and James Monaco (2009), which are informed by structural linguistics.

14. A1 transcribes the audio track of Auden's reading in correspondence with the spelling of the first edition of his poem in The London Magazine in 1965; the German spelling and punctuation in the transcription of the superimposed audio track A2 follow Herbert Heckmann's translation, which, however, has 'umzäuntem Rasen' ['enclosed lawn'] instead of 'ungezäunten Rasen' ['unenclosed lawns'].

15. 'So stolz die Kirchstettner auf Josef Weinheber sind - sie haben einen Platz und sogar die Volksschule nach ihm benannt - so stolz sind sie auch auf Wystan Auden' (00:16:2600:16:35).

16. 'Deutschlands Genius, Deutschlands Herz und Haupt. / Ehre Deutschlands, ihm so lang geraubt. / Macht des Schwerts, daran die Erde glaubt. // Fünfzig Jahre, und ein Werk aus 
Erz. / Übergroß, gewachsen an dem Schmerz. / Hell und heilig, stürmend höhenwärts. // Retter, Löser, der die Nacht bezwang. / Ernte Du auch, dulde Kranz und Sang: / Ruh' in unsrer Liebe, lebe lang!' (Weinheber 1939, 1). The first letters of each line spell out the title 'Dem Führer.'

17. The Austrian TV profile includes a second poem by Auden: 'The Letter' from 1927 - 'das erste, glaube ich, das ich behalten habe' ['the first, I believe, I have kept'] (00:04:2500:04:28). Superimposed over the audio track of Auden's own reading is the narrator's voice-over synopsis: 'Ein melancholisches Gedicht von dem Wechsel der Jahreszeiten und der Liebe. Und von einem Brief, in dem vieles steht, nur nicht, dass es ein Wiedersehen geben wird' ['A melancholic poem of the change of seasons and of love. And of a letter in which much is written, except that there will be a reunion'] (00:05:03-00:05:14).

18. In 1958, when W. H. Auden and his partner Chester Kallman were spending their first summer in Austria, Auden wrote to his Austrian acquaintance Hedwig Petzold from Kirchstetten, 'We both love it here and like the Austrians though I do think them a little Reichsinnig. ... The Germans are much less sympathetic but they do feel some guilt at what they did - the Austrians none at all' (Davenport-Hines 1995, 297).

19. Charles Osborne's Auden biography, following conductor Robert Craft's account, reports that it was at a Stravinsky dinner party in Berlin that Auden spoke about 'the film that the Austrian government has been making of his life in Kirchstetten': 'One scene is in church - not terribly appropriate, perhaps (a naughty bar might have been more suitable) but you can hear me singing. Besides, the priest loved being photographed and got all dolled up for it. You can also hear me speaking Kraut, ungrammatical, no doubt, but chatty, and I get in some echt expressions' $(1995,279)$.

20. On 15 December 1965, W. H. Auden wrote to his brother Bernard that the BBC programme was 'quite well done,' even though the interview had not been without friction: 'There was one moment when I lost my temper and said "For God's sake, dont [sic] ask such bloody silly questions"' (Davenport-Hines 1995, 323).

\section{Acknowledgements}

I wish to thank the editors and the anonymous reviewer for their stimulating criticism, and Professor Monika Seidl of the University of Vienna for her feedback and support.

\section{Disclosure statement}

No potential conflict of interest was reported by the author.

\section{Funding}

This work was supported by the University of Vienna and the Vienna Doctoral Academy: Theory and Methodology in the Humanities.

\section{Notes On Contributor}

Timo Frühwirth is a $\mathrm{PhD}$ candidate at the University of Vienna and Graduate Fellow at the Vienna Doctoral Academy: Theory and Methodology in the Humanities. He teaches Cultural Studies at the University of Vienna's Department of English and American Studies.

\section{ORCID}

Timo Frühwirth (D) http://orcid.org/0000-0002-3997-5193 


\section{References}

Altman, Rick. 1999. Film/Genre. London: British Film Institute.

Ang, Ien. 2008. "Cultural Studies." In The SAGE Handbook of Cultural Analysis, edited by Tony Bennett, and John Frow, 227-248. Los Angeles: SAGE.

Auden, W. H. 1940. "Refugee Blues." In Another Time, 85-86. New York: Random House.

Auden, W. H. 1965. “Joseph Weinheber (1892-1945).” London Magazine, July: 21-24.

Auden, W. H. 1966. About the House. London: Faber and Faber.

Auden, W. H. 1973. "Joseph Weinheber." Translated by Herbert Heckmann. In Gedichte: Poems, 134-141. Vienna: Europaverlag.

Auden, W. H. 1977. The English Auden: Poems, Essays and Dramatic Writings 1927-1939. Edited by Edward Mendelson. London: Faber and Faber.

Baldick, Chris. 2015. "Parallelism.” In The Oxford Dictionary of Literary Terms, 266. 4th ed. Oxford: Oxford University Press.

Berger, Albert. 1999. Josef Weinheber 1892-1945: Leben und Werk - Leben im Werk. Salzburg: Otto Müller Verlag.

Berger, Albert. 2003. "Dienende Kunst: Lyrik im öffentlichen Raum 1938-1945 am Beispiel Josef Weinhebers." In Die "österreichische" nationalsozialistische Ästhetik, edited by Ilija Dürhammer, and Pia Janke, 145-158. Vienna: Böhlau Verlag.

Boorstin, Daniel J. 1962. The Image: Or, What Happened to the American Dream. New York: Atheneum.

Brunsdon, Charlotte, and David Morley. 1978. Everyday Television: "Nationwide". London: British Film Institute.

Burke, Kenneth. 1969. A Grammar of Motives. Berkeley: University of California Press.

Burstall, Christopher, dir. 1965a. "Poet of Disenchantment: W. H. Auden.” In Sunday Night. British Broadcasting Company. Dialogue Script.

Burstall, Christopher. 1965b. "Portrait Gallery.” Sunday Times Magazine, November 21: 22, 24.

Carpenter, Humphrey. 1981. W. H. Auden: A Biography. London: George Allen \& Unwin.

Colburn, Nadia Herman. 2004. "Bibliographic Essay and Review of Auden Studies." In The Cambridge Companion to W. H. Auden, edited by Stan Smith, 240-246. Cambridge: Cambridge University Press.

Davenport-Hines, Richard. 1995. Auden. London: Heinemann.

Firchow, Peter Edgerly. 2002. W. H. Auden: Contexts for Poetry. Newark: University of Delaware Press.

Firchow, Peter Edgerly. 2008. "W. H. Auden and Josef Weinheber: Poets of Kirchstetten." In Strange Meetings: Anglo-German Literary Encounters From 1910 to 1960, 219-246. Washington, D.C.: Catholic University of America Press.

Foucault, Michel. 1979. "Truth and Power: An Interview with Alessandro Fontano and Pasquale Pasquino.” In Michel Foucault: Power, Truth, Strategy, edited by Meaghan Morris, and Paul Patton, 29-48. Sydney: Feral Publications.

Galan, F. W. 1985. Historic Structures: The Prague School Project, 1928-1946. Austin: University of Texas Press.

Hall, Stuart. 1980. “Encoding/Decoding." In Culture, Media, Language: Working Papers in Cultural Studies 1972-1979, edited by Stuart Hall et al., Centre for Contemporary Cultural Studies, University of Birmingham, 117-127. London: Routledge.

Hall, Stuart. 1996. "Cultural Studies and its Theoretical Legacies." In Stuart Hall: Critical Dialogues in Cultural Studies, edited by David Morley, and Kuan-Hsing Chen, 261-274. London: Routledge.

Hall, Stuart. 1999. "Whose Heritage? Un-Settling 'The Heritage', Re-Imagining the Post-Nation." Third Text 13 (49): 3-13. doi: 10.1080/09528829908576818.

Hamilton, Nigel. 2007. Biography: A Brief History. Cambridge, MA: Harvard University Press.

Holzinger, Dieter O., dir. 1967. “W. H. Auden.” In Das österreichische Porträt. Österreichischer Rundfunk.

Hood, Stuart. 1965. “The Box at the Opera." Spectator, December 3: 17. 
Kroon, Richard W. 2010. “Match Dissolve.” In A/V A to Z: An Encyclopedic Dictionary of Media, Entertainment and Other Audiovisual Terms, 408. Jefferson, NC: McFarland.

Lanham, Richard A. 1991a. "Metaphor." In A Handlist of Rhetorical Terms, 100-101. 2nd ed. Berkeley: University of California Press.

Lanham, Richard A. 1991b. "Simile." In A Handlist of Rhetorical Terms, 140. 2nd ed. Berkeley: University of California Press.

Levy, Alan. 1983. W.H. Auden: In the Autumn of the Age of Anxiety. Sag Harbor, New York: The Permanent Press.

Mayoral, José Antonio. 2001. "Parallelism.” Translated by A. Ballesteros. In Encyclopedia of Rhetoric, edited by Thomas O. Sloane, 552-553. Oxford: Oxford University Press.

Mendelson, Edward. 2004. “The European Auden.” In The Cambridge Companion to W. H. Auden, edited by Stan Smith, 55-67. Cambridge: Cambridge University Press.

Monaco, James. 2009. How to Read a Film: Movies, Media, and Beyond. 4th ed. Oxford: Oxford University Press.

Nadin, Mihai. 1998. “Parallelism.” In Encyclopedia of Semiotics, edited by Paul Bouissac, 465-467. New York: Oxford University Press.

Osborne, Charles. 1995. W. H. Auden: The Life of a Poet. London: Michael O’Mara.

Quinn, Justin. 2013. “At Home in Italy and Austria, 1948-1973.” In W. H. Auden in Context, edited by Tony Sharpe, 56-66. Cambridge: Cambridge University Press.

Quinn, Justin. 2015. “Auden's Cold War Fame.” In Auden at Work, edited by Bonnie Costello, and Rachel Galvin, 231-249. Houndmills: Palgrave Macmillan.

Rathkolb, Oliver. 1991. Führertreu und gottbegnadet: Künstlereliten im Dritten Reich. Vienna: Österreichischer Bundesverlag.

Schlösser, Hermann. 2014. “'Neighbour and Colleague': Notes on W. H. Auden's Poem 'Joseph Weinheber." Translated by Jonathan Quinn. In Silence Turned Into Objects: W. H. Auden in Kirchstetten, edited by Ricarda Denzer, and Monika Seidl, 376-389. St. Pölten: Literaturedition Niederösterreich.

Seidl, Monika. 2014. "'In and out of the House: The 'Publicly Private' World of Thanksgiving for a Habitat." In Silence Turned Into Objects: W. H. Auden in Kirchstetten, edited by Ricarda Denzer, and Monika Seidl, 392-409. St. Pölten: Literaturedition Niederösterreich.

Smith, Stan. 2004. "Introduction." In The Cambridge Companion to W. H. Auden, edited by Stan Smith, 1-14. Cambridge: Cambridge University Press.

Turner, Graeme. 2014. Understanding Celebrity. 2nd ed. Los Angeles: SAGE.

Updike, John. 1966. “Auden Fecit.” In Picked-Up Pieces, 235-241. New York: Random House.

Weinheber, Josef. 1939. "Dem Führer (zum 20. April 1939).” Das Innere Reich: Zeitschrift für Dichtung, Kunst und deutsches Leben, April: 1.

Weinheber, Josef. 1972a. “Auf das Unabwendbare.” In Sämtliche Werke: Die Hauptwerke, edited by Friedrich Jenaczek, 288-290. Salzburg: Otto Müller Verlag.

Weinheber, Josef. 1972b. “Kammermusik (Eine Variation).” In Sämtliche Werke: Die Hauptwerke, edited by Friedrich Jenaczek, 441-442. Salzburg: Otto Müller Verlag.

Weinheber, Josef. 1996. "Kirchstetten / Für Dr. Walter Birk, Arzt in Kirchstetten.” In Sämtliche Werke: Gedichte, Fragmente, Nachträge, Aphoristisches, edited by Friedrich Jenaczek, 479-480. Salzburg: Otto Müller Verlag.

Williams, Raymond. 1961. The Long Revolution. London: Chatto \& Windus.

Williams, Rebecca. 2016. "Localebrities, Adopted Residents, and Local Characters: Audience and Celebrity in a Small Nation.” Celebrity Studies 7 (2): 154-168. doi: 10.1080/19392397.2015. 1045303. 